\title{
REGRESSION MODELS FOR DETERMINING DEPENDENCIES ON VARIOUS FACTORS ON THE RAILWAY LINE ZOHOR - ZÁHORSKÁ VES
}

\begin{abstract}
Public passenger transport is presented as an opportunity to achieve future goals for establishing sustainable transportation systems. These systems are demanded from every member country of the EU for securing an ecologically friendly, fast, and reliable way of traveling in regions. Railway passenger transport is proven as a reliable and capable way of connecting regions. In many EÚ countries, railway transport has a certain gap, that could be improved without significant investments. In this study, we are focusing on negative consequences emerging from the cancelling operation of passenger transport on the chosen railway track. Most of the cancelations are affected by external influences. Individual car transport presents significant reasons with a noticeable impact on the potential of railway passenger transport in every region. On the railway line addressed in this article, passenger transport was cancelled in December 2019. This step was implemented for the constantly declining number of passengers. The object of the research is statistical dependence, characterized by the fact that the dependent variable is affected not only by independent variables but also by other unspecified variables and random effects. They are often called model faults or errors. This fact must be captured in a mathematical expression in a regression model. Based on this decision, it is necessary to seek answers to this situation using regression models that show the relationships between the number of passengers carried and the factors influencing their development. The main hypothesis is that the canceled of passenger transport was caused by low use by passengers. For example, with an increase/decrease in population, the number of passengers should increase/decrease the article verifies the dependences of the use of railway transport on the population of individual municipalities and on the development of fuel prices. Various dependencies (linear, polynomial, etc.) are used to test hypotheses. Testing of these dependencies will be performed using Fisher-Snedecor distribution. In the final part, the article also deals with the possibilities of using this line, as freight railway transport is no longer operated on this line. The research was carried out by a case study.
\end{abstract}

Keywords: railway line, infrastructure manager, regression line, correlation analysis

\author{
Juraj Čamaj ${ }^{1}$ \\ ${ }^{1}$ Faculty of Operation and Economics of Transport and Communications University of Žilina, \\ Univerzitná 8215/1,01026 Žilina; +421/415133434; juraj.camaj@fpedas.uniza.sk \\ Štefan Čarný ${ }^{2}$ \\ ${ }^{2}$ Faculty of Operation and Economics of Transport and Communications University of Žilina, \\ Univerzitná 8215/1, 01026 Žilina; +421/41 513 3434; stefan.carny@fpedas.uniza.sk \\ Adrián Šperka ${ }^{3}$ \\ ${ }^{3}$ Faculty of Operation and Economics of Transport and Communications University of Žilina, \\ Univerzitná 8215/1, 01026 Žilina; +421/41 513 3434; adrian.sperka@fpedas.uniza.sk
}

\section{Introduction}

The performance of passenger rail transport in Slovakia is increasing every year. For example, between 2017 and 2018, the number of passengers increased by 1,018,000 (ZSSK, 2020). However, this does not play to individual lines. In particular, the regional lines, which in recent years have experienced a recovery in the form of renewal of passenger transport (Zvolen - Šahy; Bánovce and Ondavou - Vel'ké Kapušany), in 2019 again fell into decline. This also applies to the Zohor-Záhorská Ves line. Despite the fact that it is included in the integrated transport system of the Bratislava region, the number of passengers on this line has decreased every year. For this reason, the Ministry of Transport, as the client of railway transport, in agreement with the Bratislava self-governing region decided to stop passenger transport on this line to change the schedule of train transport (in 2019 it fell on 15 December).

The objective of the article is to use statistical analysis tools to determine the causes and dependencies between passenger depletion and the external effects on passengers.
At the same time, it proposes measures that could help revive the transport needs. The usual case of stopping passenger transport leads also to stopping of freight transport and railway infrastructure is slowly declining. The infrastructure manager does only basic maintenance of the line so that it can be operated by potential subjects.

The solution of this problem is influenced, for example by the economic situation in the state (Dolinayová, 2019), the requirements of the state budget, which have the performance of passenger rail transport on regional lines (Dolinayová, 2018) and the efficiency of passenger transport operation on regional lines (Dolinayová, 2017). The article will present the dependencies between the number of passengers, the number of inhabitants in the villages through which the line passes and the price of fuel.

\subsection{Characteristics of the railway line from the technical point of view}

The line is classified as a regional line with a total length of $14,511 \mathrm{~km}$. The track is constructed for $60 \mathrm{~km} / \mathrm{h}$. 
The track has a normal gauge of $1435 \mathrm{~mm}$ and track is not electrified. The train normative length is $230 \mathrm{~m}$. The beginning of the track is in Plavecký Mikulaš railway station and end of the track is in Záhorská Ves railway station. Braking distance is $700 \mathrm{~m}$ (ZSR, 2020). The track includes two railway bridges and three railway crossings (Vlaky.net, 2019). Table 1 is describing the individual control points on the railway line.

Table 1. Operating control points and posts on the railway line

\begin{tabular}{|l|l|l|}
\hline Railway stations & Loading place with halt & \multicolumn{1}{c|}{ Halts } \\
\hline Zohor & Vysoká pri Morave & Lábske Jazero \\
\hline Záhorská Ves & & Vysoká pri Morave \\
\hline
\end{tabular}

Vysoká pri Morave stop has been closed since December 2006 and trains do not stop there (ŽSR, 2006). The line security is secured with telephone communication 1 st category of security. There is a mechanical station security device in the Vysoká pri Morave and Záhorská Ves transport stations. There are one transport and one handling track in the loading depot with the Vysoká pri Morave stop. There is a total of two transport tracks and one handling track in the Záhorská Ves railway station. None of the above transport is occupied by transport employees. Simplified railway traffic management is introduced on the entire line with the abolished reporting obligation [8].

\subsection{Characteristics of the railway line form the transport point of view}

The last timetable schedule of passenger transport $2018 / 2019$ was operated by 8 pairs of trains on working days and three pairs of trains on weekends and holidays. In the summer of 2019, another pair of tourist train Záhorská Ves - Plavecké Podhradie was added (ŽSR, 2018). Figure 1 displays the railway timetable for the direction Zohor - Záhorská Ves.

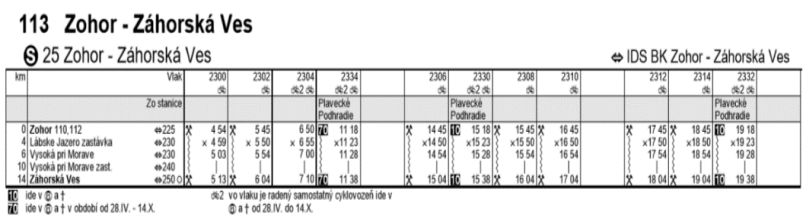

Fig. 1. Route timetable Zohor - Záhorská Ves [10]

It is clear from the timetable that the trains are operated mainly in the morning and afternoon rush hours in an hourly interval. In the notes in the header, each train has a bicycle symbol, which means that the carrier on the trains offered to transport the bicycle until the capacity is depleted.

Figure 2 displays the train schedule for the opposite direction, Záhorská Ves - Zohor.

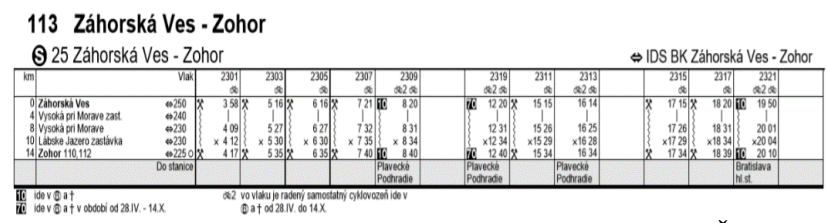

Fig. 2. Route timetable Záhorská Ves - Zohor (ŽSR, 2018)

\section{Regression models}

The aim of the use of regression models in the investigation is a deeper penetration into the essence of the observed phenomena (stopping passenger traffic on the line) and processes in a certain area. When solving, we get to the so-called causal links. A causal relationship between two phenomena is a state where the existence of one phenomenon is related to the existence of another phenomenon (Hindls, 2003). Table 2 lists the types of dependencies investigated.

Table 2. Division of aspects of research methods

\begin{tabular}{|l|l|}
\hline $\begin{array}{c}\text { Type of } \\
\text { dependencies }\end{array}$ & \multicolumn{1}{c|}{ Characteristic } \\
\hline fixed dependence & $\begin{array}{l}\text { the occurrence of one phenomenon is } \\
\text { necessarily responsible for the occurrence } \\
\text { of another phenomenon }\end{array}$ \\
\hline free dependence & $\begin{array}{l}\text { the occurrence of one phenomenon affects } \\
\text { the occurrence of another phenomenon } \\
\text { only in the form of probability }\end{array}$ \\
\hline
\end{tabular}

\section{Examination of dependency}

When examining this dependence, a free dependence will be used, because in the studied phenomena it is not certain to what extent the indicators will be dependent.

One-sided dependencies are dealt with by regression analysis. This is a state where the explanatory (independent) variable in the role of causes and the explained (dependent) variable in the role of consequences stand against each other (Hindls, 2003). Table 3 lists the individual dependencies examined.

\subsection{Values on the vertical axis}

The vertical axis will include data on population and fuel prices for the period from 2007 to 2016 .

Table 4 shows the population of the Zohor, Vysoká pri Morave, and Záhorská Ves. Knowingly that Lábske Jazero is the only nature reservation and the nearest village is Láb, $4,3 \mathrm{~km}$ away from the railway station, we will not take its population into the count (Statistics, 2020).

Table 3. Number of inhabitants in individual municipalities

\begin{tabular}{|l|l|l|}
\hline Place & Year & Population \\
\hline \multirow{4}{*}{ Zohor } & 2007 & 3297 \\
\cline { 2 - 3 } & 2008 & 3330 \\
\cline { 2 - 3 } & 2009 & 3335 \\
\cline { 2 - 3 } & 2010 & 3330 \\
\hline & 2011 & 3207 \\
\cline { 2 - 3 } & 2012 & 3224 \\
\hline
\end{tabular}




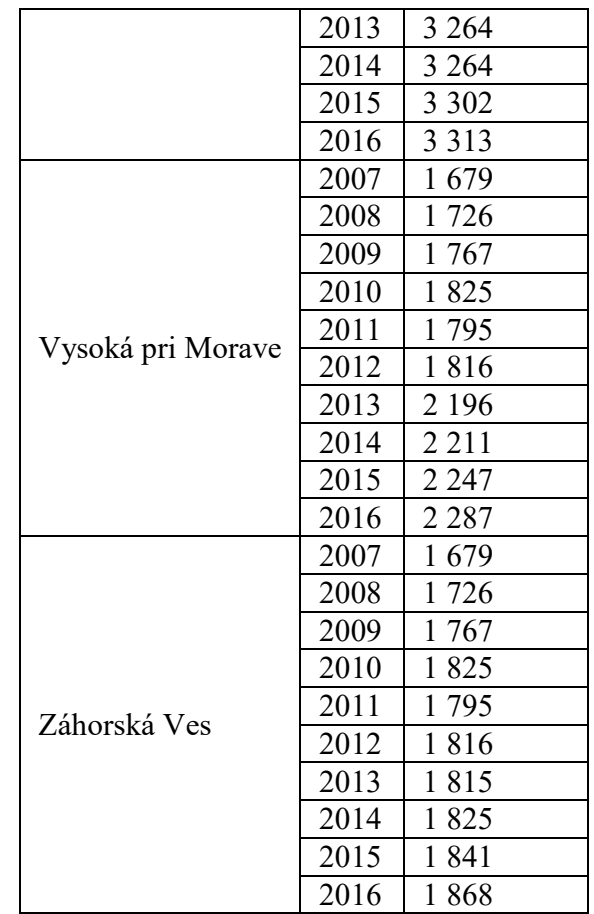

It is clear from the table that the number of inhabitants in individual municipalities gradually increased. This was also due to the fact that the inhabitants of the capital moved to the countryside, due to more affordable real estate prices. In Vysoká na Morave and Záhorská Ves, you can see a year-on-year decrease in the population in the period 2010 and 2011. Fuel prices per litre of petrol 95 in the observed period are shown in the graph in figure 3 . The prices are represented in $€$.

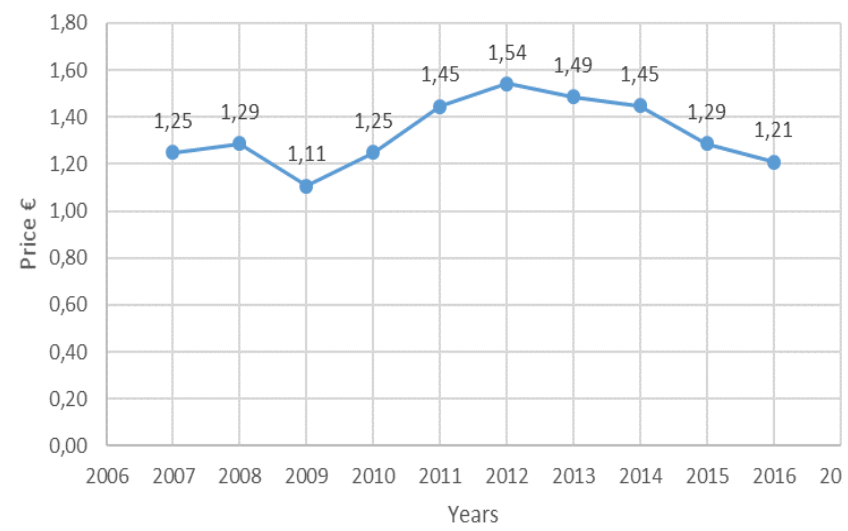

Fig. 3. Development of fuel prices (Autoplan.sk, 2020)

The lowest fuel price was observed in 2019 when the prices were at $1,11 €$ for a litre.

On the contrary, in 2012 the price peaked at 1,54€ per litre.

\subsection{Values on the horizontal axis}

The horizontal axis shows the number of passengers carried on a given route. As these data are internal and are not published by the carrier, it is necessary to determine the approximate number of passengers for the reference period using a transport model.

The transport model talks about the burden on public passenger transport (bus and rail) by passengers in 24 hours. It is being prepared for the current period and is also used to implement the traffic forecast (there is currently a scenario until 2050). According to the transport model, the load on rail transport represents intensity of $0-5,000$ passengers in 24 hours (MDV, 2014). For the purposes of this article, we will count on an average occupancy of 83 passengers, which is also the capacity of seats in the engine unit. According to Equation 1, we determined the number of passengers per year.

Number of passengers per year $=$ number of passengers in 24 hours *365 (1).

After setting the values, we get an average of 30,295 passengers a year. In the next step, using the data in the carrier's annual report, we will determine the percentage share of power on the line to the total share of power on the network (ZSSK, 2018).

Percentage of passengers carried $=$ number of passengersper year/number of passengers carried (2).

The individual shares of shipments for the observed period are shown graphically in percentages in Figure 4.

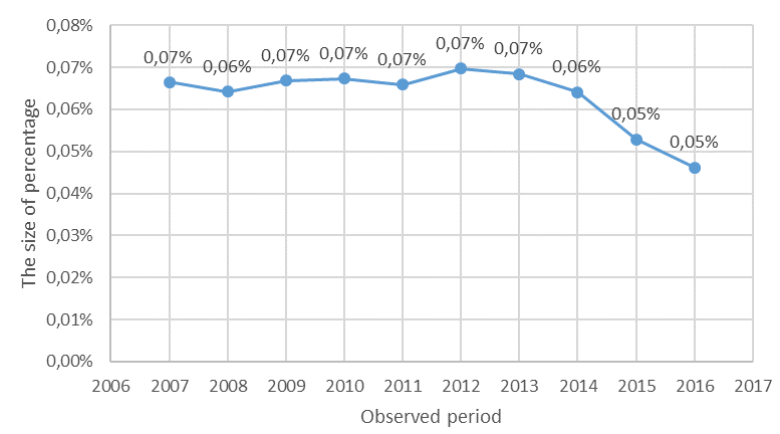

Fig. 4. Share of transport performance in percentage on the railway line Zohor - Záhorská Ves

During the entire period under review, the share of output remained in the range from $0.05 \%$ (in 2015 and 2016) to $0.07 \%$. Performance on this line has been relatively stable, but despite the introduction of free transport for selected population groups, performance has declined slightly in recent years.

In the final step, the number of passengers in the observed period is calculated using Equation 3.

Number of passengers on the line $=$ number of all passengers * percentage of passenger carried (3)

Figure 5 shows the approximate average number of passengers for the period 2007-2016. 


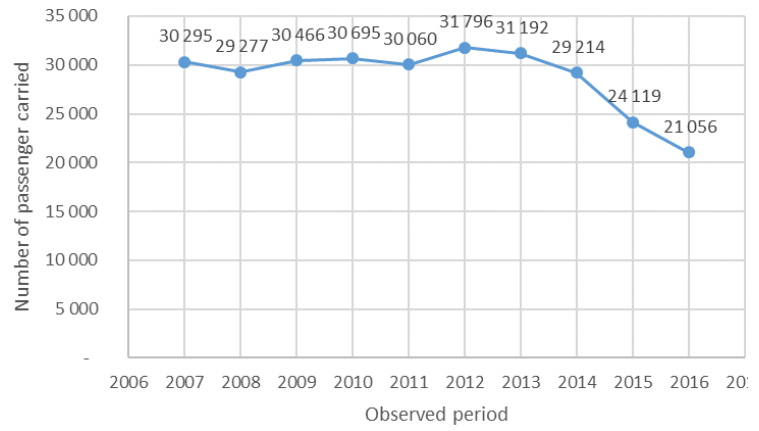

Fig. 5. The number of passengers carried for the period

The number of passengers begins to decline after the year 2014. Before the year 2014, the number of passengers was relatively stable.

\subsection{F-test}

To determine the dependence between the observed phenomena, the so-called F-test. An F-test is any static test in which the test statistic has a distribution of $F$ assuming the null hypothesis is valid. It is most used when comparing statistical models that have been estimated from a data set to identify the model that most closely matches the population from which the data were collected. Exact F-tests arise mainly when the models were estimated using the least-squares method.

If the tabular value of the F-test is less than the calculated value, it can be stated that the investigated quantities are dependent. However, if the tabular value of the F-test is greater than the calculated value, it can be stated that the investigated quantities are not dependent. We use Equitation 5 to calculate the F-test value.

$$
\mathrm{F}=\left(\mathrm{R}^{2} / \mathrm{k}\right) /\left(1-\mathrm{R}^{2}\right) / \mathrm{n}-\mathrm{k}+1
$$

where:

$\mathrm{k}$ - coefficient (for a linear dependence it takes the value 1 and for a polynomial dependence it takes the value 2) $\mathrm{n}$ - number of years in the reference period $\mathrm{R}^{2}$ - reliability equation (coefficient of determination)

\section{Testing statistical hypotheses}

To begin with, it is necessary to establish hypotheses, that we will either accept or reject after testing. These are listed in Table 5.

Table 4. Determination of statistical hypotheses

\begin{tabular}{|l|l|}
\hline $\mathrm{H}_{0}$ & $\begin{array}{l}\text { The number of passengers } \\
\text { depends on the population }\end{array}$ \\
\hline $\mathrm{H}_{1}$ & $\begin{array}{l}\text { The number of passengers is } \\
\text { independent of the population }\end{array}$ \\
\hline $\mathrm{H}_{0}$ & $\begin{array}{l}\text { The number of passengers } \\
\text { depends on the development of } \\
\text { fuel prices }\end{array}$ \\
\hline $\mathrm{H}_{1}$ & $\begin{array}{l}\text { The number of passengers is } \\
\text { independent of the development of } \\
\text { fuel prices }\end{array}$ \\
\hline
\end{tabular}

3.1 Examination of the relationship between the number of passengers carried and the number of inhabitants

In examining this relationship, we will use a linear dependence, since the reliability equation $\mathrm{R}^{2}$ was the highest for this function. When plotting a simple regression model, we will use the data in Table 4 and Figure 5. A graphical representation is shown in Figure 6.

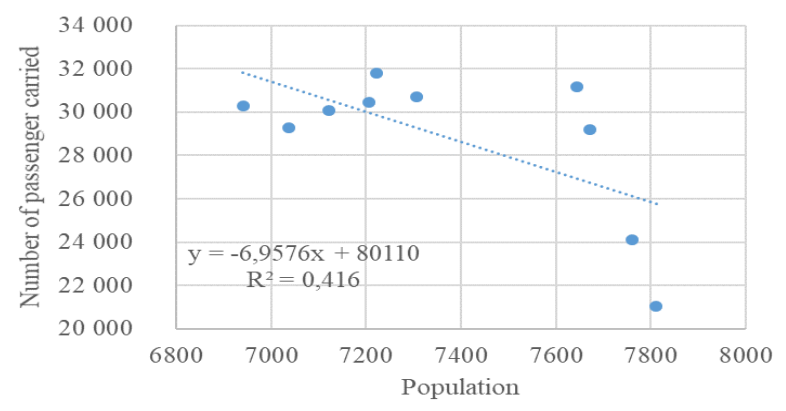

Fig. 6. The linear relationship between the number of passengers carried and the number of inhabitants

To verify the dependence, it is necessary to form a table. The table should display the individual variables in which dependency or independence will be verified. This verification is in table 6 .

Table 5. Dependency verification

\begin{tabular}{|l|l|}
\hline $\mathrm{R}^{2}$ & 0,42 \\
\hline $\mathrm{k}$ & 1 \\
\hline $\mathrm{n}$ & 10 \\
\hline $\mathrm{n}-(\mathrm{k}+1)$ & 8 \\
\hline $\mathrm{F}$ & 5,70 \\
\hline $\mathrm{F}_{\mathrm{TAB}}$ & 5,32 \\
\hline
\end{tabular}

We can see from the table that the calculated value of the F-test, according to Equation 5, is larger than the table value. Based on this fact, it can be concluded that it is possible to accept hypothesis $\mathrm{H}_{0}$ and reject Hypothesis $\mathrm{H}_{1}$. After 2016, the number of passengers continued to fall. This is even though the weekend seasonal operation of motor trains on the route Záhorská Ves - Plavecké Podhradie and back has been introduced. Passengers prefer to use bus transport, which is characterized by a larger number of connections and more stops in individual villages, which also plays a significant role. In addition, a large part of the population uses individual transport (passenger car) for transfers.

\subsection{Examination of the relationship between the number of passengers carried and fuel prices}

In examining this correlation, we use a polynomial dependence, since the reliability equation $\mathrm{R}^{2}$ was the highest at this dependence. In plotting this dependence, we will use the data in Figures 3 and 5. A graphical representation of the results is shown in Figure 7. 


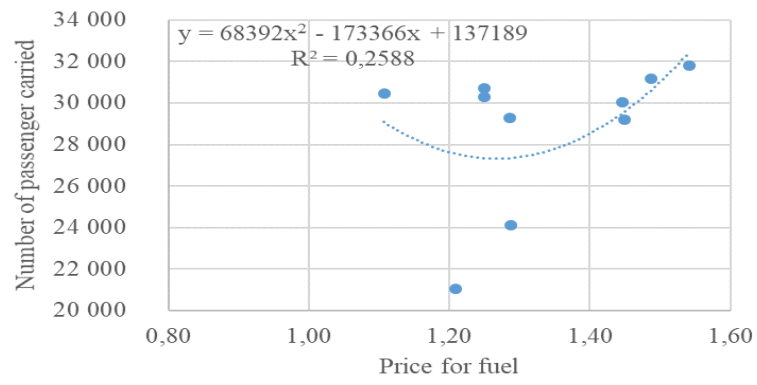

Fig. 7. Polynomial relationship between the number of passengers carried and the price for fuel

To verify the dependence, it is necessary to form a table. The table should display the individual variables in which dependency or independence will be verified. This verification is in table 7 .

Table 6. Dependency verification

\begin{tabular}{|l|l|}
\hline $\mathrm{R}^{2}$ & 0,26 \\
\hline $\mathrm{k}$ & 2 \\
\hline $\mathrm{n}$ & 10 \\
\hline $\mathrm{n}-(\mathrm{k}+1)$ & 7 \\
\hline $\mathrm{F}$ & 1,23 \\
\hline $\mathrm{F}_{\mathrm{TAB}}$ & 4,74 \\
\hline
\end{tabular}

It is clear from the table that the number of passengers does not depend on the prices of fuel. The tabular value of the F-test is higher than the value of the calculated Ftest. In this case, we accept the hypothesis $\mathrm{H}_{1}$ and reject hypothesis $\mathrm{H}_{0}$.

\section{Conclusion}

Regional rail passenger transport has been experiencing a slowdown recently. To revive it, it is necessary to examine the various factors and dependencies that characterize it. The article presented two factors, the dependence of which on the number of passengers carried was examined. The number of inhabitants of individual municipalities depended on the number of transported passengers. In practice, this means that if the population increases, the number of rail passengers should increase. However, negligible factors, such as the degree of motorization or competing bus transport.

The second dependence examines the number of transported passengers and the price of fuel. However, these factors are independent of each other.

Passenger transport was toped on the line in December 2019. The factors examined above were also signed under this step will be such as e. g. extensive marketing research or interest in the renewal of passenger transport, harmonization of railway transport and road transport, or expansion of the seasonal operation.

\section{References}

ZSSK, 2020. Železničná spoločnost' Slovensko. a. s., Years book, [Online]. Available: https://www.zssk.sk/wp-
content/uploads/2019/08/Vyrocnasprava_SK_2018_FINAL_WEB.pdf. [Cit. 10 Jún 2020].

Dolinayová, A., Černá, L., Zitrický, V., Daniš, J., 2019. Impact of the economic situation in the Slovak Republic on performances of railway transport. In: Periodica Polytechnica: Transport Engineering, 47(2), pp. 118 - 123

Dolinayová, A., Černá, L. 2018. Passenger and freight transport performances in the regional railway line and their impact to the state budget requirements - case study in Slovakia. In: Transport Means 2018: proceedings of the international scientific conference, Kaunas, Lithuania.

Dolinayová, A., Černá, L., Daniš, J. 2017. Regional railways transport - effectiveness of the regional railway line. In: Sustainable rail transport: proceedings of RailNewcastle 2017, Newcastle, 2017.

Kuruc, L. 2001. Slovenské Železnice, 1st ed., Bratislava, PHOENIX, 280 p., ISBN 80-900563-2-6

ŽSR, 2020. Table of track condition, Železnice Slovenskej republiky, [Online] Available: https://www.zsr.sk/files/sps/OstatneDokumenty/Dopr ava/Tabulky-tratovych-pomerov/Aktualne-TTP/TTP126-C-Plavecky-Mikulas-Zahorska-Ves-30z.pdf.

Vlaky.net, 2019. Available: https://www.vlaky.net/trate/4/zsr-113-zohorzahorska-ves/\#tratTab2.

ŽSR, 2009. Leaflets of GVD 2010, Železnice Slovenskej republiky, Bratislava

ŽSR, 2006. Timetable of ŽSR 2006/2007, Železnice Slovenskej republiky, , Bratislava

ŽSR, 2018. Timetable of ŽSR 2006/2007, Železnice Slovenskej republiky, , Bratislava

Hindls, R. Hronová, S., Seger, J. 2003. Statistika pro ekonomy, 5th ed., Praha: Professional Publishing, 420 p., ISBN 80-86419-34-7

Statistics, 2020. Počet obyvatel'ov podla pohlavia, Štatistický úrad Slovenskej republiky, Available: http://datacube.statistics.sk/\#!/view/sk/VBD_DEM/o m7101rr/v_om7101rr_00_00_00_sk.

Autoplan.sk, 2020. Priemerné ceny PHM zo štatistického úradu, A-CORY s. r. o. - Ekonomický softvér, Available:

https://www.autoplan.sk/informacie/sadzbyzakladnej-nahrady/priemerne-ceny-phm-pre-roky/.

MDV, 2014. Inštitút dopravnej politiky, Ministerstvo dopravy a výstavby Slovenskej republiky, Available: https://www.mindop.sk/ministerstvo-1/doprava3/dopravne-modelovanie/dopravny-modelsr/zaverecna-sprava.

ZSSK, 2019. Years book 2018, Available: https://www.zssk.sk/wpcontent/uploads/2019/08/Vyrocnasprava_SK_2018_FINAL_WEB.pdf. [Cit. 12 Jún 2020]. 